\title{
The Future of the European Court of Human Rights in the Era of Radical Democracy
}

\author{
Armen Harutyunyan \\ Judge of the European Court of Human Rights, Strasbourg, France \\ Armen.Harutyunyan@echr.coe.int
}

The values of the European Convention on Human Rights ('ECHR' or 'Convention'), which underpin the activity of the Council of Europe as a whole, are increasingly called into question, both at the European and at the global levels. The threats posed by terrorism, mass migration, nationalist rhetoric, populism and the rise of radical democracies ${ }^{1}$ have offered populism fertile ground to flourish. As a result, the defence of minority interests - which is inherent in the protection of fundamental rights - is under attack. Moreover, one cannot guarantee that the situation caused by coviD19 will not be used to further nationalistic and populist agendas - although the pandemic has also revealed humankind's global solidarity, prompting us to realise that the only possible way to fight this threat effectively is through co-operation.

The weaker the political will to comply with the Convention is, the more problematic the job of national institutions becomes. This is one reason explaining why in many countries people see the European Court of Human Rights ('ECtHR' or 'Court') as the only avenue to protect their rights. Indeed, for many people, this institution is their last hope. Yet, the emergence of different forms of 'radical' democracies in the 2ooos has challenged the Convention system in its entirety. Presumably, this danger was initially underestimated; however, the present day conditions compel us to tackle this problem.

1 By radical democracy is meant a model of governance having a democratic facade in the absence of real separation of powers and a system of checks and balances. Per se, it is an authoritarian regime. 
The Court's evolution between the Cold War era and the 1980s is well documented. ${ }^{2}$ This was the period when the Court was perceived by the parties to the ECHR as the unquestionable, ultimate, last-word interpreter of the Convention. This period is characterised by the formulation of most of the Convention's principles of interpretation, the ECHR's very purpose being 'the promotion of the ideals and values of a democratic society'. ${ }^{3}$ Unfortunately, relatively recent developments have shown how fragile democracy can be. It is an age-old truism that dialogue is necessary between a supranational authority, such as the ECtHR, and states parties' national authorities. However, dialogue can be seriously undermined by the unwillingness of the national authorities to engage in a constructive relationship with the ECHR system. Such phenomena have been observed in the early 2ooos, concerning, in particular, some new Council of Europe member states, whose regimes have been described in scholarship as regimes ranging from authoritarianism, or semi-competitive authoritarianism, to illiberal democracies. ${ }^{4}$

Indeed, in a number of countries, the ruling elites rely on a 'democratic' method of government which is based on the majority rule. ${ }^{5}$ Liberalism accepts the majority rule as a method, but not as the only or the exclusive indicator as to what the solution to a problem should be. Quite the contrary, for doctrinal democrats, the fact that the majority wishes something is a sufficient reason to consider this as appropriate. The will of the majority does not only determine the content of the law, but also its appropriateness as law. Ultimately, doctrinal democrats only recognise one criterion, the opinion prevailing within the majority. Unlike doctrinal democrats, the liberal democrats believe that minority opinions and wishes should also be heard and discussed. For the liberal democrat, democracy also means a system of guarantees for the minority, not a dictatorship of the majority. Thus, liberal democracy is primarily concerned with limiting the 'aggression' of the majority as, indeed, the danger of the dictatorship of the majority is a real one. ${ }^{6}$

MR Madsen, 'From Cold War Instrument to Supreme European Court: The European Court of Human Rights at the Crossroads of International and National Law and Politics' (2007) 32(1) Law and Social Inquiry 137.

3 Kjeldsen, Busk Madsen and Pedersen $v$ Denmark 5095/71, 5920/72 and 5926/72 (ECtHR, 7 December 1976) para 53 .

See S Levitsky and LA Way, Competitive Authoritarianism: Hybrid Regimes After the Cold War (Cambridge University Press 2010); see also M Ottaway, Democracy Challenged: The Rise of Semi-Authoritarianism (Carnegie Endowment for International Peace 2003).

6 FA Hayek, The Constitution of Liberty (University of Chicago Press 1960) 90-102. 
The nicety of the modern global situation lies within the fact that, very often, having lost the support of the majority in a society, the political majority tries to retain power by using the state apparatus and the mechanisms to exercise power, populism and manipulative technologies. ${ }^{7}$ This leads to a situation where, what used to be a political majority, becomes a ruling minority that lacks support in a society and does not represent general interests. This is very often complemented by suppression of the opposition and by a total disregard of human dignity, which is the basis of fundamental rights and freedoms. An important reason why a political majority can lose its legitimacy to govern is because it does not govern based on the rule of law. Gradually, such a ruling majority can turn into a dictatorship of the majority. After losing public support, the dictatorship of the majority can then be transformed into a minority dictatorship, lacking roots in or support from the society. ${ }^{8}$ This is how a democracy can turn into a radical democracy. Presently, a number of authoritarian states try to present themselves as democratic by pretending to replicate the model of governance of Western democracies and the liberal institutions supporting this model within these democracies. However, because such states do not really transfer any meaningful powers and authority to the institutions underpinning the liberal democracy model of governance, these falsified copies have been a source of disappointment for people. ${ }^{9}$

Democracy in the case law of the ECtHR is mainly concerned with representation and participation. Thus, democracy in the context of the Convention must be understood as participatory democracy showing respect for differences of opinion and belief; ${ }^{10}$ not as democracy in the formal/doctrinal sense, ie a radical democracy exclusively relying on the majority rule. Democracy translates into Convention standards of pluralism, tolerance and broadmindedness, and requires the protection of substantive rights.

In the theory of constitutional law and in political science, it has been argued that the existence of a democracy depends on respect for political and civil rights and freedoms. This allows qualifying or labelling democratic countries as maximum or minimum democracies ${ }^{11}$ - whilst other qualifications may

7 Nowadays, populism has become one of the most dangerous challenges for democracy and the rule of law.

8 A Harutyunyan, Constitutionalism: Problems of Post-Soviet Realities (Norma 2013) 125-127 (in Russian).

9 This process is explained in detail in the book by I Krastev and S Holmes, The Light that Failed: Why the West Is Losing the Fight for Democracy (Pegasus 2020).

10 Ždanoka v Latvia [GC] 58278/oo (ECtHR, 16 March 2006).

11 See, for instance, MJ Sodaro, Comparative Politics: A Global Introduction (3rd edn, McGrawHill 2008) 177-178. 
apply as well for 'new democracies'. ${ }^{12}$ In any case, the core problem is that the dynamics of modern, global - including pan-European - processes reveal how countries - formally presenting themselves as democracies but, essentially, being authoritarian ones - can challenge human rights and democracy. That is, anti-democratic democracies and anti-constitutional constitutionalism are emerging in a number of states..$^{13}$ By default, illiberal democracies, 'semi-democracies' or radical democracies are challenging democracy.

It is within this context that one must assess the cases concerning the detention/imprisonment of journalists ${ }^{14}$ and human rights defenders, ${ }^{15}$ as well as the targeting of opposition politicians ${ }^{16}$ that the Court is increasingly being asked to deal with. It is noteworthy that, as early as 1978 , the Court held that democracy within the ECHR framework concerns the balance between the rights of the individual and the democratic pursuit of the public interest. ${ }^{17}$ In 1998, the Court explicitly highlighted that democracy is the only political model compatible with the Convention, whereas the protection of the Convention rights is necessary to safeguard the values of a democratic society. ${ }^{18}$ Yet, as pointed out by Richard Bellamy:

International Human Rights Courts, such as the ECtHR, have come under increasing criticism as being incompatible with domestic judicial and legislative mechanisms for upholding rights. These domestic instruments are said to possess greater democratic legitimacy than international instruments do or could do. ${ }^{19}$

In response, the Court has emphasised the principle of subsidiarity, and the 'fourth-instance' and the margin of appreciation doctrines. In particular, the Court endeavours to highlight the ideas of: 1) shared responsibility; 2) the

12 See Levitsky and Way (n 4); see also Ottaway (n 4).

13 A Harutyunyan, 'Anti-Constitutional Constitutionalism: Minority Against Minority (Its Impact on International Law)' in PP de Albuquerque and K Wojtyczek (eds), Judicial Power in a Globalized World: Liber Amicorum Vincent de Gaetano (Springer 2019) 221. See Fatullayev v Azerbaijan 40984/o7 (ECtHR, 22 April 2010); Nedim Şenerv Turkey 38270/11 (ECtHR, 8 July 2014).

15 Rasul Jafarovv Azerbaijan 69981/14 (ECtHR, 17 March 2016).

16 Merabishvili v Georgia [GC] 72508/13 (ECtHR, 28 November 2017); Lutsenko v Ukraine 6492/11 (ECtHR, 3 July 2012).

$17 \quad$ Klass and Others $v$ Germany 5029/71 (ECtHR, 6 September 1978).

18 United Communist Party of Turkey and Others $v$ Turkey [GC] 133/1996/752/951 (ECtHR, 30 January 1998).

19 R Bellamy, 'The Democratic Legitimacy of International Human Rights Conventions: Political Constitutionalism and the European Convention on Human Rights' (2014) 25(4) The European Journal of International Law 1019. 
primary role being held by the national institutions in the protection of human rights; 3) and the causes of incompatibility of national practices with the Convention being found at the domestic level, as the Court just performs scrutiny (often based on European consensus). The ECtHR is not a fourth instance court.

According to the principle of subsidiarity, the primary responsibility to protect human rights rests with states. This means that the ECtHR's role is subsidiary/secondary. The Court acts as the last instance for individuals and private entities, whose rights the national institutions failed to protect. The principle of subsidiarity can be briefly described in the following way. First of all, the applicant must seek the protection of the domestic authorities in the first place to give them the opportunity to remedy the alleged violation. Secondly, the ECtHR must respect the national authorities' autonomy, particularly the autonomy of the national judiciary authorities - if they adhere to the principles of interpretation of the Convention and they do not contradict the standards set by the Court. Finally, the true application of the subsidiarity doctrine increases the effectiveness of the national institutions, in particular because it underlines their primary responsibility for ensuring the rights and freedoms guaranteed by the Convention. The essence of the margin of appreciation doctrine is that the national institutions are in the best position to determine the facts of a case, evaluate them, and ensure a balance of interests taking into account the specificities of the national legal system and social order. Subsidiarity is associated with the margin of appreciation method of interpretation, which enables the Court to remain connected with 'legal reality' by providing the possibility to treat the Convention differentially, whilst conditionally enabling European supervision. This approach is clearly reflected, for example, in the cases Nejdet Sahin and Perihan Sahin $v$ Turkey ${ }^{20}$ and Varga and Others $v$ Hungary. ${ }^{21}$

In fact, the ECtHR relies on the following two basic principles when interpreting the Convention: the rule of law and democracy. As Geranne Lautenbach puts it: 'The rule of law is one of the central values underlying the Convention.'. ${ }^{22}$ The Court has described rule of law as a notion from which the

$20 \quad$ Nejdet Şahin and Perihan Şahin v Turkey [GC] 13279/05 (ECtHR, 20 October 2011).

21 Varga and Others $v$ Hungary 14097/12, 45135/12, 73712/12, 34001/13, 44055/13 and 64586/13 (ECtHR, 10 March 2015). See, DJ Harris, M O'Boyle, EP Bates, CM Buckley, Harris, O'Boyle and Warbrick. Law of the European Convention on Human Rights (4th edn, Oxford University Press 2018) 14-18.

22 G Lautenbach, The Concept of the Rule of Law and The European Court of Human Rights (Oxford University Press 2013) 11-13; Broniowski v Poland [GC] 31443/96 (ECtHR, 22 June 2004) para 184. 
whole Convention draws its inspiration. ${ }^{23}$ Moreover, the Court has indicated that the implementation, protection and promotion of individual human rights are possible only within democracy. Only then one can speak of the principle of subsidiarity which implies the primary role of the national institutions in the protection of human rights, because only under such conditions the existence of effective remedies is really possible as required by Article 13 ECHR. If one endeavours to conceptualise the Court's approach towards democracy and the rule of law, then democracy is the regime that guarantees the protection of minority interests. Of course, a minority opinion can change into a majority one through free elections and other avenues of representation in a liberal model of governance. A democratically elected majority does not yet mean that it is democratic as such. For this to happen, it is also necessary to adhere to the rule of law principle, which involves a system of checks and balances, and compliance with fundamental rules such as human rights. Otherwise, the regime is leaning towards a dictatorship of the majority model, ie the aforementioned radical democracy regime.

Quite to the contrary, democracy is the regime that provides individual autonomy in private and public relations. Democracy requires the protection of human rights and rule of law as a means to ensure minority rights. The rule of law-based democratic regime is the only environment where the effective protection of human rights and freedoms is possible; and the Convention relies upon the idea that the Council of Europe member states share these values. Democracy is the regime where the rule of law is the principle and the medium, and the effective protection of human rights and freedoms is the object and purpose. This regime, and its underpinning principles, purposes and mechanisms of effective implementation are interrelated and interdependent, ie one cannot exist without another. However, when the dynamism of social development moves towards authoritarianism, rather than democracy, then the process is reversed from democracy to authoritarianism. In such circumstances, the ECtHR is the only hope for the citizens of the countries departing from liberal democratic values.

Yet, the ECtHR is neither a national court nor a fourth instance court. The ECtHR jurisprudence constantly holds that the Court is not an additional instance of appeal against national courts. Its powers do not include the elimination of errors of fact or law allegedly made by the national courts. ${ }^{24}$

\footnotetext{
23 Engel and Others $v$ The Netherlands 5100/71, 5101/71, 5102/71 and 5370/72 (ECtHR, 8 June 1976) para 69. See more on this: Lautenbach (n 22) 11-13.

24 D Spielmann, 'The European Court of Human Rights: Master of the Law but not of the Facts?' (speech to the British Institute of International and Comparative Law, 6 November 2014): <https://www.echr.coe.int/Documents/Speech_20141106_Spielmann_BIICL.pdf>.
} 
Nevertheless, the ECtHR can question the interpretation of the law by the courts in cases where this interpretation is 'arbitrary and manifestly ill-founded. ${ }^{25}$

Next to the states which continue to uphold the special role of the ECtHR in the interpretation of the Convention, one can find states which increasingly challenge the Court's authority and/or demand sharing the interpretation tasks with the ECtHR. This is not a problem per se. The Court has acknowledged in several instances that the national approaches regarding a given human rights issue differ from one state to another. Such differences are sometimes conceptual. In these cases, the Court can apply the European consensus method. In the absence of consensus, it recognises that the margin of appreciation of the national authorities is wider. It is in these conditions, that the ECtHR has to highlight the necessity of the ongoing dialogue with national authorities, but also distinguish between state conduct in good and in bad faith, with the latter scenario resulting in the violation of Article 18 of the Convention, which the Court is increasingly finding to be breached. ${ }^{26}$ The main challenge faced by the Convention system is the absence of overall respect for the Convention. A necessary condition for dialogue is the political will of the states. The principle of subsidiarity, the margin of appreciation technique and the 'fourth instance' doctrine, all open the window of opportunity to co-operate in a state sovereignty-friendly manner. The ECtHR sets minimum standards of guarantees and protects human rights in a manner that in principle meets with the consensus of the Council of Europe member states. It can be said that, on the regional level, the ECHR and the ECtHR case law are in a sense a cultural and civilisational point of reference, uniting 47 - maximum and minimum - democracies.

Within this socio-legal environment, the most pertinent question now is the extent to which some states will depart from the rule of law and the premises of liberal democracy. What kind of new geopolitical and geo-economic challenges are the Council of Europe and its member states going to face? What are the ECHR red lines? What are the limits of compromise?

25 Anđelković $v$ Serbia 1401/o8 (ECtHR, 9 April 2013).

26 Selahattin Demirtaşv Turkey (No. 2) [GC] 14305/17 (ECtHR, 22 December 2020); Navalnyy $v$ Russia (No. 2) 43734/14 (ECtHR, 9 April 2019); Ibrahimov and Mammadov v Azerbaijan 63571/16, 74143/16, 2883/17, 289o/17, 39527/17 and 39541/17 (ECtHR, 13 February 2020). 